\title{
Characterization of Vibrio harveyi, the Causal Agent of Vibriosis in Cultured Marine Fishes in Korea
}

\author{
Kyoung-Mi Won ${ }^{1}$, Su Mi Kim ${ }^{1}$ and Soo Il Park ${ }^{*}$ \\ Department of Aquatic Life Medicine, Pukyong National University, Busan 608-737, Korea \\ ${ }_{2}^{2}$ Institute of Fisheries Sciences, Pukyong National University, Busan 608-737, Korea
}

\begin{abstract}
An epizootic causing mortality among cultured marine finfishes occurred in 1999 in the province of Kyoungsang, Korea. The disease was characterized by the presence of enterocele, abdominal swelling, and gastroenteritis. The causative bacteria were isolated from olive flounder (Paralichthys olivaceus), black rockfish (Sebastes schlegeli), turbot (Scophthalmus maximus) and the rearing water. These bacteria showed swarming activity on agar plates and yellowish or greenish colonies on thiosulfate-citrate-bile salts-sucrose (TCBS) agar plates, but no luminescence. The pathogen was identified as Vibrio harveyi based on morphological and biochemical characteristics and the sequence of $16 \mathrm{~S}$ rDNA. The lethal doses $\left(\mathrm{LD}_{50}\right)$ of olive flounder and black rockfish were estimated to be $1.24 \times 10^{6}-1.36 \times 10^{8}$ and $3.24 \times 10^{5}-5.8 \times 10^{7} \mathrm{CFU} /$ fish respectively following intraperitoneal injection.
\end{abstract}

Key words: Olive flounder, Vibrio carchariae, Vibrio harveyi, Swarming activity, Pathogenicity

\section{Introduction}

Vibrio species belong to the autochthonous microbial flora of marine organisms and are among the most important groups in marine environments (Tsukamoto et al., 1993). Various Vibrio species have been demonstrated to be the causative agents of disease in cultured marine fishes (Austin and Austin, 1999; Liao et al., 1996). Recently, outbreaks of serious mortality in cultured marine fishes, which displayed gastroenteritis, occurred in the United States and Taiwan (Soffientino et al., 1999; Yii et al., 1997). A new type of epizootic causing mortality among cultured marine finfishes occurred in Kyoungsang Province, Korea in 1999. Characteristic symptoms of this disease include the presence of enterocele, abdominal swelling, and gastroenteritis. The causative bacteria were identified as swarming Vibrio harveyi.

In this report, we describe the first isolation and characterization of a swarming Vibrio obtained from diseased olive flounder (Paralichthys olivaceus), black rockfish (Sebastes schlegeli) and turbot (Scophthalmus maximus) during summer in Korea. The pathogenicity of the isolated bacterium to olive flounder and black rockfish was assessed by a

\footnotetext{
*Corresponding author: parksi@pknu.ac.kr
}

challenge test.

\section{Materials and Methods \\ Bacterial culture}

We used 16 isolates from several different sources, hosts and geographical locations as well as two type strains ( $V$. harveyi ATCC14126 and $V$. carchariae ATCC35084; Table 1). The cultures were grown routinely on tryptic soya agar (TSA; Difco, Grand Island, NY, USA) supplemented with $1.5 \%(\mathrm{w} / \mathrm{v})$ sodium chloride (TNA) at $27^{\circ} \mathrm{C}$, except tests of growth in diverse $\mathrm{NaCl}$ concentrations and temperatures. Stock cultures were stored at $-80^{\circ} \mathrm{C}$ in nutrient broth (Difco) with 10\% (v/v) glycerol.

\section{Biochemical and physiological characterization}

Sixteen isolates and two type strains were examined for the production of oxidase, catalase and key phenotypic characteristics in accordance with standard methods (MacFaddin, 2000).

\section{Morphological characterization}

Morphological tests of five strains of $V$. harveyi (FF8, FF10, FR1, FR2, and FT1) were conducted via Gram- and negative staining. The negative straing samples were fixed in $2.5 \%$ glutaraldehyde and stained with $4 \%$ uranyl acetate and then observed 
Table 1. Isolates and type strains used in this study

\begin{tabular}{|c|c|c|c|}
\hline Strains & & Origin of bacteria & \\
\hline \multirow{6}{*}{ Isolated strains $(n=16)$} & FT1 & Kidney of turbot*** & Koungsan Province, 1999 \\
\hline & $\begin{array}{l}\text { FF1 } \\
\text { FF2 } \\
\text { FF3 } \\
\text { FF4 } \\
\text { FF5 } \\
\text { FF6 }\end{array}$ & $\begin{array}{l}\text { Flounder rearing water } \\
\text { Kidney of olive flounder* } \\
\text { Flounder rearing water } \\
\text { Eye of olive flounder } \\
\text { Kidney of olive flounder } \\
\text { Spleen of olive flounder }\end{array}$ & Koungsang Province, 1999 \\
\hline & $\begin{array}{l}\text { FF7 } \\
\text { FF8 } \\
\text { FF9 }\end{array}$ & $\begin{array}{l}\text { Ascitic fluid of olive flounder } \\
\text { Ascitic fluid of olive flounder } \\
\text { Intestinal fluid of olive flounder }\end{array}$ & Koungsang Province, 1999 \\
\hline & $\begin{array}{l}\text { FF10 } \\
\text { FF11 }\end{array}$ & $\begin{array}{l}\text { Kidney of olive flounder } \\
\text { Liver of olive flounder }\end{array}$ & Busan, 1999 \\
\hline & FR1 & Kidney of black rockfish** & Koungsang Province, 1999 \\
\hline & $\begin{array}{l}\text { FR2 } \\
\text { FR3 } \\
\text { FR4 }\end{array}$ & $\begin{array}{l}\text { Kidney of black rockfish } \\
\text { Surface lesion of black rockfish } \\
\text { Black rockfish rearing water }\end{array}$ & Busan, 1999 \\
\hline \multirow{2}{*}{ Type strains $(n=2)$} & ATCC35084 & Kidney of brown shark & $\begin{array}{l}\text { Grimes et al., } 1984 \\
\text { Vibrio carchariae type strain }\end{array}$ \\
\hline & ATCC14126 & Dead, luminescing amphipod & $\begin{array}{l}\text { Baumann et al., } 1980 \\
\text { Vibrio harveyi type strain }\end{array}$ \\
\hline
\end{tabular}

*Olive flounder, Paralichthys olivaceus; ${ }^{* *}$ Black rockfish, Sebastes schlegeli; ${ }^{* * *}$ Turbot, Scophthalmus maximus

under transmission electron microscopy (TEM; JEM 1200-II, JEOL, Tokyo, Japan).

\section{DNA isolation and 16S rDNA gene sequencing}

Five strains of $V$. harveyi (FF8, FF10, FR1, FR2, and FT1) were grown in tryptic soy broth (TSB; Difco) at $27^{\circ} \mathrm{C}$ for $24 \mathrm{~h}$, harvested by centrifugation and washed twice in TE buffer $(10 \mathrm{mM}$ Tris-HCl, 1 mM EDTA, pH 7.6). Cells were lysed and DNA was isolated using a DNAzol kit (Gibco), following the manufacturer's protocol. The DNA templates were amplified by the polymerase chain reaction (PCR) on a Perkin Elmer (Wellesley, MA, USA) Gene Amp PCR system 2400, using primer set 1 which amplifyed a 1350 -bp region of the $16 \mathrm{~S}$ rDNA gene (forward, 5'-GTTTGATCATGGCTCAGATT-3'; reverse, 5'-TTACTAGCGATTCCGACTTC-3') and a primer set 2 for subcloning (forward, 5'-CATTATTTGACGTTAGCGAC-3'; reverse, 5'-TGGAGTTCCACCCGAAGTG-3'), obtained from Bioneer (Daejeon, Korea). The DNA templates were amplified by initial denaturation at $94^{\circ} \mathrm{C}$ for $5 \mathrm{~min}$, followed by 30 cycles of denaturation at $94^{\circ} \mathrm{C}$ for $30 \mathrm{sec}$, annealing at $55^{\circ} \mathrm{C}$ for $30 \mathrm{sec}$, extension at $72^{\circ} \mathrm{C}$ for $7 \mathrm{~min}$. Sequencing of the amplified DNA fragment was performed by using an automatic sequencer (ABI 377; Perkin Elmer). The resulting sequences were used to construct a phylogenic tree by the neighbour-joining method followed by bootstrap test (Mega 2.1 version).

\section{Determination of luminescence in isolates}

For the visual test of luminescence, all tested strains were checked in a dark room after a 20-min period of dark adaptation. In addition, cultures grown in TSB medium for $24 \mathrm{~h}$ were measured with luminometer (LumiCount BL10001; Packard, Meriden, CT, USA) either with or without exposure to the lightstimulating agent, $n$-decyl aldehyde $(0.2$ and $0.5 \%$ $[\mathrm{v} / \mathrm{v}])$. The luminescent strain $V$. harveyi ATCC 14126 was used as a positive control. For the detection of the luciferase gene, which introduces bacterial luminescence, the DNA templates were amplified by PCR using LuxA primers (Ramaiah et al., 2000) which amplify a 405-bp region of the luciferase gene (forward, 5'-CTACTGGATCAAATGTCAAAAGGACG-3'; reverse, 5'-TCAGAACCGTTTGCTTCAAAACC-3'), obtained from Bioneer. The PCR conditions were as above.

\section{Challenge experiments}

Healthy olive flounder weighting $5 \pm 1.2 \mathrm{~g}$ and black rockfish weighting $30 \pm 1.5 \mathrm{~g}$ were obtained from a fish farm in Korea and held in aquaria at $23 \pm$ $0.5^{\circ} \mathrm{C}$. Ten animals were used for each of the eight experimental groups. Five strains of $V$. harveyi (FF8, FF10, FR1, FR2, and FT1) and two type strains cultured on TSA at $27^{\circ} \mathrm{C}$ for $24 \mathrm{~h}$ were suspended in a physiological saline (PS). Fish in the experimental groups were injected intraperitoneally with $0.1 \mathrm{~mL}$ of 
bacterial cell suspensions $\left(10^{6}, 10^{7}, 10^{8}\right.$, and $10^{9}$ colony-forming units $[\mathrm{CFU}] / \mathrm{mL}$ ), respectively. The control group was injected intraperitoneally with 0.1 $\mathrm{mL}$ of PS. Dead and moribund fish were removed and subjected to standard bacteriological and pathological examinations. Mortality was recorded daily for 7 days, and the lethal doses $\left(L_{50}\right)$ were calculated using the probit method described by Wardlaw (1985). Each experiment was conducted twice.

\section{Results}

\section{Biochemical and physiological characterization}

Biochemical characteristics of the 16 isolates and type strains of $V$. harveyi and $V$. carchariae are shown in Table 2. Isolates were similar to each other in biochemical characteristics, but were diverse in their utilization of sucrose and sorbitol. Effects of $\mathrm{NaCl}$ concentrations and temperatures on growth of the pathogen are shown in Table 3.

\section{Morphological characterization}

Isolates were Gram-negative rods and had a polar flagellum. However, When the isolates were cultured on agar plates, their shapes changed to much longer cells with many additional lateral flagella compared to those in broth culture (Fig. 2).

\section{S rDNA gene sequencing}

Sequencing of the $16 \mathrm{~S}$ rDNA gene revealed that the isolates showed 100 and $99.1 \%$ similarities to the type strains, ATCC35084 and ATCC14126, respectively (Genetyx program; Software Development Inc. Tokyo, Japan). The phylogenic tree based on the rRNA sequence is shown in Fig. 3.

\section{Determination of luminescence in isolates}

The five isolates did not show bioluminescence in either the visual or the luminometer test. The luciferase gene was not detected in any isolate. In contrast, positive luminescence of $V$. harveyi ATCC14126 was confirmed by luminometer and the $405-b p$

Table 2. Comparison of biochemical characteristics of the isolated strains with the type strains

\begin{tabular}{|c|c|c|c|c|c|c|c|}
\hline \multirow[b]{2}{*}{ Characteristics } & \multicolumn{5}{|c|}{ Isolated strains } & \multicolumn{2}{|c|}{ Type strains } \\
\hline & $\begin{array}{c}\text { Flounder } \\
(\mathbf{n}=7)^{*}\end{array}$ & $\begin{array}{c}\text { Flounder } \\
(n=4)\end{array}$ & $\begin{array}{c}\text { Rockfish } \\
(n=2)\end{array}$ & $\begin{array}{c}\text { Rockfish } \\
(n=2)\end{array}$ & $\begin{array}{l}\text { Turbot } \\
(n=1)\end{array}$ & $\begin{array}{l}\text { ATCC } \\
35084\end{array}$ & $\begin{array}{l}\text { ATCC } \\
14126 \\
\end{array}$ \\
\hline Gram stain & - & - & - & - & - & - & - \\
\hline Motility & + & + & + & + & + & + & + \\
\hline Luminescence & - & - & - & - & - & - & + \\
\hline Oxidase & + & + & + & + & + & + & + \\
\hline Catalase & + & + & + & + & + & + & + \\
\hline Simmon's citrate & + & + & + & + & + & + & + \\
\hline Nitrate & + & + & + & + & + & + & + \\
\hline Indole & + & + & + & + & + & + & + \\
\hline Methyl red & + & + & + & + & + & + & + \\
\hline Voges-Proskauer & - & - & - & - & - & - & - \\
\hline \multicolumn{8}{|c|}{ Decarboxylase production } \\
\hline Lysine & + & + & + & + & + & + & + \\
\hline Ornithine & + & + & + & + & + & + & + \\
\hline \multicolumn{8}{|c|}{ Dehydrolase production } \\
\hline Arginine & - & - & - & - & - & - & - \\
\hline \multicolumn{8}{|l|}{ Acid from } \\
\hline Arabinose & - & - & - & - & - & - & - \\
\hline Glucose & + & + & + & + & + & + & + \\
\hline Sorbitol & - & $+(3)$ & $-(1)$ & - & + & - & - \\
\hline Raffinose & - & - & - & - & - & - & - \\
\hline Sucrose & + & - & + & - & + & + & + \\
\hline Salicin & - & $-(2)$ & $-(1)$ & - & - & - & - \\
\hline Lactose & - & $-(3)$ & - & - & - & - & - \\
\hline Inositol & - & - & - & - & - & - & - \\
\hline Maltose & + & + & + & + & + & + & + \\
\hline Mannose & + & + & + & + & + & + & + \\
\hline Mannitol & + & + & + & + & + & + & + \\
\hline Melibiose & - & $+(3)$ & $-(1)$ & + & - & - & + \\
\hline Urease prodution & $-(5)$ & $-(3)$ & $-(1)$ & - & + & + & - \\
\hline TCBS & $+(Y)$ & $+(G)$ & $+(Y)$ & $+(G)$ & $+(Y)$ & $+(Y)$ & $+(Y)$ \\
\hline
\end{tabular}

( ), number of strains that showed a response; $(\mathrm{Y})$, all yellow colony; $(\mathrm{G})$, all green colony; *, isolated fish. 
Table 3. Effects of $\mathrm{NaCl}$ concentration and temperature on the growth of isolates

\begin{tabular}{|c|c|c|c|c|c|c|c|}
\hline \multirow{2}{*}{ Effects of } & \multicolumn{5}{|c|}{ Isolated strains } & \multicolumn{2}{|c|}{ Type strains } \\
\hline & FF 8 & FF 10 & FR 1 & FR 2 & FT 1 & ATCC35084 & ATCC 14126 \\
\hline \multicolumn{8}{|c|}{ Concentration $(\%)$ of $\mathrm{NaCl}$ in $\mathrm{TSB}\left(27^{\circ} \mathrm{C}\right)$} \\
\hline 0 & - & - & - & - & - & - & - \\
\hline 0.5 & + & + & + & + & + & + & + \\
\hline 1 & + & + & + & + & + & + & + \\
\hline 3 & + & + & + & + & + & + & + \\
\hline 5 & + & + & + & + & + & + & + \\
\hline 7 & - & - & - & - & + & + & + \\
\hline \multicolumn{8}{|c|}{ Incubation temperature $\left({ }^{\circ} \mathrm{C}\right)$ in TSA $(2 \% \mathrm{NaCl})$} \\
\hline 4 & - & - & - & - & - & - & - \\
\hline 10 & - & - & - & - & - & - & - \\
\hline 27 & + & + & + & + & + & + & + \\
\hline 37 & + & + & + & + & + & + & + \\
\hline 40 & - & - & - & - & - & - & - \\
\hline
\end{tabular}

luciferase gene band was detected in this type strain (data not shown).

\section{Challenge experiments}

Table 4 shows the pathogenicity of five isolates and two type strains in olive flounder and black rockfish. The $\mathrm{LD}_{50}$ of olive flounder was estimated at $1.24 \times 10^{6}-1.36 \times 10^{8} \quad \mathrm{CFU} /$ fish following intraperitoneal injection, and the FR2 strain was the most virulent in olive flounder $\left(1.24 \times 10^{6} \mathrm{CFU} / \mathrm{fish}\right)$. In black rockfish, $\mathrm{LD}_{50}$ was estimated at $3.24 \times 10^{5}-5.8 \times$ $10^{7} \mathrm{CFU} /$ fish following intraperitoneal injection, and FR2 and FT1 strains were the most virulent at $3.24 \times$ $10^{5}$ and $6 \times 10^{5} \mathrm{CFU} / \mathrm{fish}$, respectively. The type strains, ATCC35084 and ATCC14126 showed very high $\mathrm{LD}_{50}$ estimates. Moribund fish of the challengetested groups showed the same signs as those of naturally infected fish.

\section{Discussion}

The bacteria isolated from diseased cultured marine fishes in Korea were identified as $V$. harveyi based on a comparison of its biochemical characteristics and 16S rDNA gene sequence to the type strains Vibrio carchariae ATCC 35084 and $V$. harveyi ATCC 14126. $V$. carchariae was first isolated from a dead sandbar shark (Carcharhinus plumbeus) at the National Aquarium in Baltimore, MD, USA, in 1982 and reported to be associated with mortality of captive sharks (Grimes et al., 1984). However, this Vibrio species has not previously been identified as a causative agent in other species of cultured marine finfishes. Following the report of Leong and Wong (1993), who observed a similar syndrome in cage-cultured grouper, Epinephelus malabaricus, more cases were reported in summer flounder, grouper, salmonids and penaeid shrimps
(Alvarez et al., 1998; Soffientino et al., 1999; Yii et al., 1997; Zhang and Austin, 2000).

In this study, we isolated $V$. harveyi from cultured marine fishes that showed enterocele, abdominal swelling, and enteritis. This is the first report for Korea. The isolated bacteria formed swarming colonies on agar plates and showed almost the same biochemical characteristics as $V$. carchariae and $V$. harveyi reported by Nishimori et al. (1998). Also, the $16 \mathrm{~S}$ rDNA gene sequence showed 100 and $99.1 \%$ similarity to those of $V$. carchariae ATCC 35084 and $V$. harveyi, respectively. As a result of the identification of these bacteria, we concluded that the bacteria are $V$. charchariae, which taxonomically, this organism is a junior synonym of Vibrio harveyi (Pedersen et al., 1998).

The effects of $\mathrm{NaCl}$ concentration and temperature on the growth of the isolates and type strains were tested (Table 3). Alsina and Blanch (1994) reported that $V$. harveyi and $V$. carchariae grew in $8 \% \mathrm{NaCl}$ and $40^{\circ} \mathrm{C}$; however, with the exception of $\mathrm{FTl}$, our isolates did not grow in $7 \% \mathrm{NaCl}$ at $40^{\circ} \mathrm{C}$.

We also confirmed the pathogenicity of the isolates to olive flounder and black rockfish using a challenge test. The $\mathrm{LD}_{50}$ estimate for the olive flounder was $1.24 \times 10^{6}-1.36 \times 10^{8} \mathrm{CFU} /$ fish, and the FR2 strain was the most virulent. In black rockfish, the $\mathrm{LD}_{50}$ estimate was $3.24 \times 10^{5}-5.8 \times 10^{7} \mathrm{CFU} /$ fish, and the FR2 and FT1 strains were the most virulent. This result that $V$. harveyi was extremely virulent to marine fishes agrees with other reports. Soffientino et al. (1999) reported that the $\mathrm{LD}_{50}$ estimate of $V$. harveyi was $5 \times$ $10^{5} \mathrm{CFU} /$ fish following intraperitoneal injection into 100-200 g summer flounder, Paralichthys dentatus. Zorrilla et al. (2003) reported that the $\mathrm{LD}_{50}$ estimate of $V$. harveyi LG-14.00 strain was $2.1 \times 10^{5} \mathrm{CFU} /$ fish fish following intraperitoneal injection into $70 \mathrm{~g}$ sole 


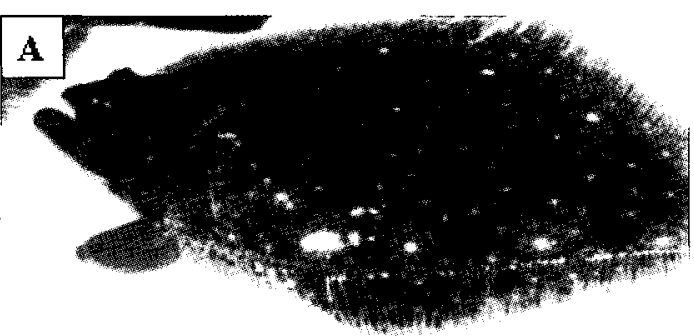

C
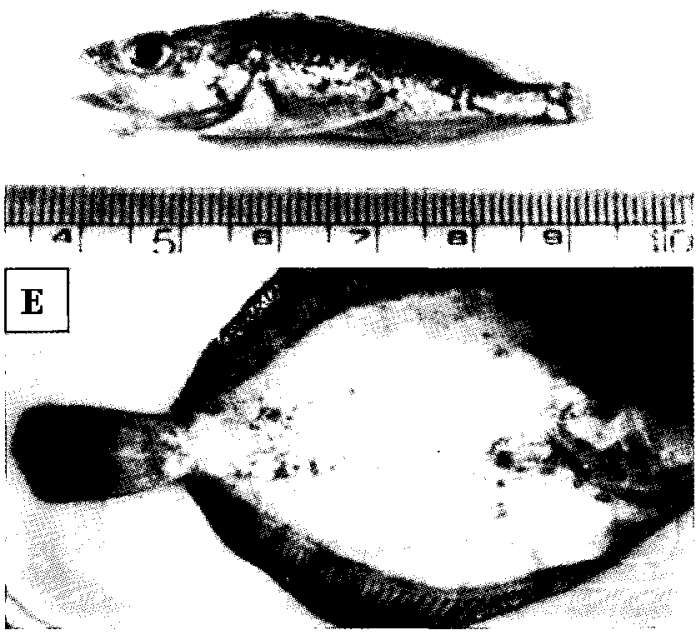

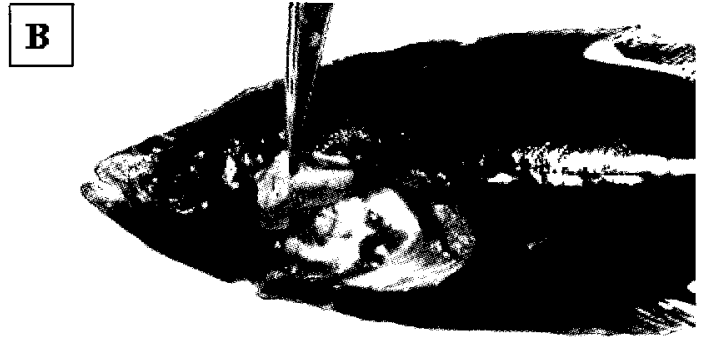

$\mathbf{D}$
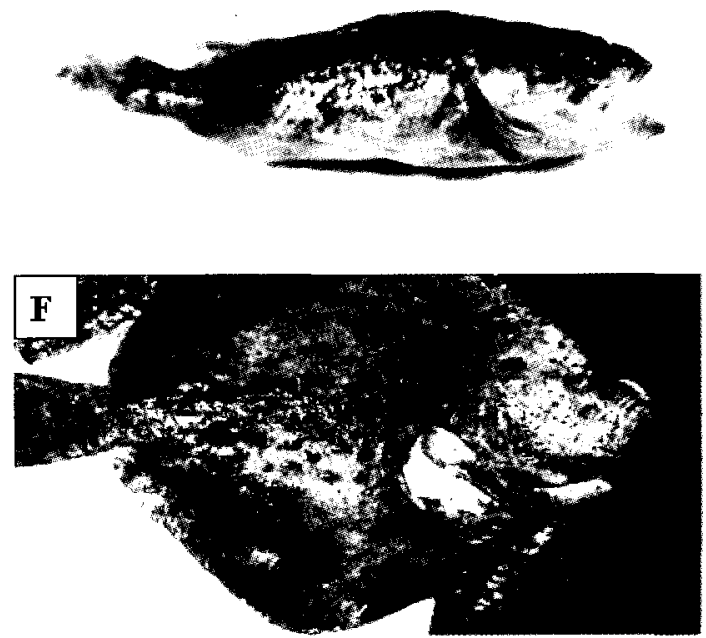

Fig. 1. Typical symptoms of olive flounder (Paralichthys olivaceus), black rockfish (Sebastes schlegeli), and turbot (Scophthalmus maximus) infected with Vibrio harveyi. A and B, infected olive flounder with enterocele and severe enteritis; $C$ and $D$, infected black rockfish with skin ulcer and hemorrhage around the mouth; $E$ and $\mathrm{F}$, infected turbot with hemorrhages on the body surface and the base of the fin and enteritis.

Table 4. The lethal dose $\left(\mathrm{LD}_{50}\right)$. of Vibrio harveyi following intraperitoneal injection in olive flounder (Paralichthys olivaceus) and black rockfish (Sebastes schlegeli) at 7 days

\begin{tabular}{lccccccc}
\hline & FF 8 & FF 10 & FR 1 & FR 2 & FT 1 & ATCC35084 & ATCC14126 \\
\hline Olive flounder & $4.8 \times 10^{7}$ & $4.38 \times 10^{8}$ & $4.38 \times 10^{8}$ & $1.24 \times 10^{6}$ & $1.36 \times 10^{8}$ & $4.38 \times 10^{8}$ & $>10^{9}$ \\
Black rockfish & $1.62 \times 10^{6}$ & $1.18 \times 10^{6}$ & $7.56 \times 10^{6}$ & $6 \times 10^{5}$ & $3.24 \times 10^{5}$ & $5.8 \times 10^{7}$ & $2 \times 10^{8}$ \\
\hline
\end{tabular}

\section{(Solea senegalensis).}

This is the first description of $V$. harveyi acting pathogenic bacteria for cultured olive flounder and black rockfish in Korea. Vibrio harveyi is ubiquitous bacterium that causes high mortality in olive flounder and black rockfish, and it is therefore necessary to carefully monitor this potential pathogen.

\section{References}

Alsina, M. and A.R. Blanch. 1994. A set of keys for biochemical identification of environmental Vibrio species. J. Appl. Bacteriol., 76, 79-85.

Alvarez, J.D., B. Austin, A.M. Alvarez and H. Reyes. 1998.
Vibrio harveyi: a pathogen of penaeid shrimps and fish in Venezuela. J. Fish Dis., 21, 313-316.

Austin, B. and D.A. Austin. 1999. Bacterial Fish Pathogens: Diseases of Farmed and Wild Fish, 3rd ed. Springer-Praxis, Godalming, UK, 1-113.

Baumann, P., L. Baumann, S.S. Bang and M.J. Woolkalis. 1980. Re-evalution of taxonomy of Vibrio, Beneckea, and Photobacterium; abolition of the genus Beneckea. Curr. Microbiol., 4, 127-132.

Grimes, D.J., J. Stemer, H. Hada, E.B. May, D. Maneval, F.M. Hetrick, R.T. Jones, M. Stoskopf and R.R. Colwell. 1984. Vibrio species associated with mortality of sharks held in captivity. Microb. Ecol., 
$10,271-282$.

Leong, T.S. and S.Y. Wong. 1993. Environmental induced mortality of cultured grouper Epinephelus malabaricus infected with high density of monogeneans and vibrios. In: Programme and Abstracts of the Second Symposium on Diseases in Asian Aquaculture. Health Section of the Asian Fisheries Society, Manila, $1-37$.

Liao, I-C., K.K. Lee and Y.H. Chien. 1996. Practical approaches to marine fish health problems in Taiwan, In: Aquaculture Health Management Strategies for Marine Fish in Asia and the United States. Main, K.L. and $\mathrm{C}$. Rosenfeld, eds. The Oceanic Institute, Honolulu, HI, USA, 57-67.

MacFaddin, J.F. 2000. Biochemical Tests for Identification of Medical Bacteria, Lippincott Williams and Wilkins, Philadelphia, PA, USA, 1-456.

Nishimori, E., O. Hasegawa, T. Numata, and H. Wakabayashi. 1998. Vibrio carchariae causes mass mortalities in Japanese abalone, Sulculus diversicolor supratexta. Fish Pathol., 33, 495-502.

Pedersen, K., L. Verdonck, B. Austin, D.A. Austin, A.R. Blanch, P.A.D. Grimont, J. Jofre, S. Koblavi, J.L. Larsen, T. Tiainen, M. Vigneulle and J. Swings. 1998. Taxonomic evidence that Vibrio carchariae Grimes et al. 1985 is a junior synonym of Vibrio harveyi (Johnson and Shunk, 1936) Baumann et al., 1981. Int. J. Syst. Bacteriol., 48, 749-758.

Ramaiah, N., J. Chun, J. Ravel, W.L. Straube, R.T. Hill and R.R. Colwell. 2000. Detection of luciferase gene sequences in nonluminescent bacteria from the Chesapeake Bay. FEMS Microbiol. Ecol., 33, 27-34.

Soffientino, B., T. Gwaltney, D.R. Nelson, J.L. Specker, M Mauel and M. Gomez-Chiarri. 1999. Infectious necrotizing enteritis and mortality caused by Vibrio carchariae in summer flounder Paralichthys dentatus during intensive culture. Dis. Aquat. Org., 38, 201210.

Tsukamoto, K.K., H. Lyaizu, K. Nanba and U. Simidu. 1993. Phylogenic relationship of marine bacteria, mainly members of the family Vibrionaceae, determined on the basis of $16 \mathrm{~S}$ rDNA sequences. Int. J. Syst. Bacteriol., 43, 8-19.

Wardlaw, A.C. 1985. Practical Statistics for Experimental Biologists. John Wiley and Sons, Chichester, UK, 551-554.

Yii, K.C., T.I. Yang and K.K. Lee. 1997. Isolation and characterization of Vibrio carchariae, a causative agent of gastroenteritis in the groupers, Epinephelus coioides. Curr. Microbiol., 35, 109-115.

Zhang, X.H. and B. Austin. 2000. Pathogenicity of $V$. harveyi to salmonids. J. Fish Dis., 23, 93-102.

Zorrilla, I., S. Arijo, M. Chabrillon, P. Diaz, E. MartinezManzanares, M.C. Balebona and M.A. Morinigo. 2003. Vibrio species isolated from diseased farmed sole, Solea senegalensis (Kaup), and evaluation of the potential virulence role of their extracellular products. J. Fish Dis., 26, 103-108.

(Received July 2006, Accepted September 2006) 